\title{
Plants and animals diversity in Buqaty Mountain Area (BMA) in Hamadan Province, Iran
}

\author{
MAHDI REYAHI-KHORAM ${ }^{1, \boldsymbol{}}$, MAJEED JAFARY ${ }^{1}$, MOSTAFA BAYATI ${ }^{1}$, REIHANEH REYAHI-KHORAM $^{2}$ \\ ${ }^{1}$ Department of Environment, Hamadan Branch, Islamic Azad University, Hamadan, Iran, P.O.BOX: 65138-734, Professor Mosivand st., Hamadan, \\ Iran Tel: +988114494170, Fax: +988114494170, `email: phdmrk@gmail.com \\ ${ }^{2}$ Department of Agricultural Engineering Food Industries, Qazvin Branch, Islamic Azad University, Qazvin, Iran.
}

Manuscript received: 17 June 2012. Revision accepted: 6 September 2012.

\begin{abstract}
Reyahi-Khoram M, Jafary M, Bayati M, Reyahi-Khoram R. 2012. Plants and animals diversity in Buqaty Mountain Area (BMA) in Hamadan Province, Iran. Biodiversitas 14: 190-194. Buqaty Mountain Area (BMA) is regarded as one of the genetic reserves of Hamadan province in Iran. BMA is highly important regarding variety of plant and animal species, but limited research work has been performed in this area in the field of biodiversity. Identifying the unique ecologic talents and capabilities and aesthetics of BMA is the most important objective of this study. This research was conducted during 2010 through 2011 in BMA to identify various plant and animal species through documentary and also direct field observations. With direct referring to the various regions of the studied area, plant samples were collected from different slope position and transported to field laboratory units. Sampling was made for every 20 meters increase in the height of area. Animal species of the area were identified too. Based on the results, about 44 valuable plant species, 45 species of birds as well as 7 species of mammals have been identified in BMA. It is recommended that the area be declared an A prohibited hunting area by Department of Environment (DoE) of Iran for the conservation of flora and fauna in the study area.
\end{abstract}

Key words: biodiversity, ecotourism, environment, habitat, pasture

\section{INTRODUCTION}

Hamadan province with a long history and record in traditional medicine was shown as one of the main centers of production and supply of herbal plants in Iran. The tomb of eminent Iranian scientist and medicine, Avicenna (Ibn Sina), is located in the heart of Hamadan city. The province covering 19,493 square kilometers and is located in the west of Iran, $320 \mathrm{~km}$ far from Tehran with a population of 1.7 million, has varied pastures and natural resources (Reyahi-Khoram and Karami-Nour 2010). Based on the available information, the flora of Hamadan province includes 6000 species of which 315 species related to 71 families and 209 genus are valuable plant drug, of which 159 species have traditional usage in the province and 156 species are out of traditional and indigenous use but they are called medicinal plants in drug resources (Kalvandi et al. 2007). Medicinal plants are widely used by the indigenous people in the treatment of various diseases (Russell-Smith 2006; Suneetha 2006; Mirutse-Giday 2009; Rihawy 2010; Tilahun-Teklehaymanot 2010; Nadembega 2011). In Iran, Medicinal plants are as a basic element of medical system. In the other word, medicinal plants are a source for a wide variety of natural antioxidants. These resources are usually regarded as part of cultural traditional knowledge (Shahidi 2004; Bouayed 2007; Koochak 2010; Mosaddegh 2012)
The acceptance of traditional medicine as an alternative form of health care and the development of microbial resistance to the classical antibiotics led researchers to investigate the antimicrobial activity of several medicinal plants (Ulukanli and Akkaya 2011). Also, demand for traditional food plants has increased significantly over recent years, particularly so over the past decade. Many species of traditional food plants have been utilized by native people of the world. Hamadan province with a range of these plant species has the potential to provide a valuable source of Traditional food plants in the area. These traditional vegetables have the potential to provide a valuable source of nutrition in areas with hot or dry climates. They could fill a valuable niche in the production of food in rural areas where the climate is not favorable to the production of vegetables. But, most of the exotic vegetables require large amounts of water for successful production. In areas where people have to walk long distances to collect their water, most water is used for domestic purposes and there is very little available for use on a vegetable garden.

Buqaty Mountain Area (BMA) is regarded as one of the genetic reserves of the province, and has a special status in this regard. Although BMA is highly important regarding variety of plant and animal species, but limited research work has been performed in this area in the field of biodiversity. Therefore, it is necessary to identifying and introducing various plant and animal species and the importance of mentioned region. Identifying the unique 
ecologic talents and capabilities and aesthetics of BMA is the most important objective of this study. Other objectives include introducing plant and animal species of this area. The said research may provide a means of identifying the threatened species and critically endangered species and also determine the effective causes of protecting and survival of the said species and may contribute to improvement of the programming and management overall study area.

\section{MATERIALS AND METHODS}

This research was conducted during 2010 through 2011 in Buqaty Mountain Area (BMA) to identify various plant and animal species through documentary, extensive field visits and also direct field observations during the years of study. Through the period, using the map, Global Positioning System (GPS) and in some cases through afoot surveying or using car, the geographical location of BMA was identified. To evaluate the climatology status of the area, data of meteorology organization was used. Means, the data of the nearest meteorology stations to the BMA including Khomigan and Nojeh Meteorology Stations were used. The analyses are based on the 21 years of available meteorological records of Khomigan and Nojeh stations. For general identification of the area, digital maps and Geographic Information System (GIS) were used and on this basis, the topological status of the area was identified
(Demers 2009). With direct referring to the various regions of the studied area, plant samples were collected from different slope position and packaged and transported to field laboratory unit. Sampling was made for every 20 meters increase in the height of area. Rectangular sampling or quadrate sampler unit was taken with a 100 square meters $(10 \mathrm{~m} \times 10 \mathrm{~m})$. Plant samples were collected in full form including stem, root, leave, and fruit and also seed parts of plants. Before sampling, the ecology and biology form of every species was recorded directly. Plants were identified according to the appearance of stem, flower and or leaf. Then the collected species were compared to the scientific literature available and every species were identified separately. Key methods for identifying various plant species in this area including the color of flower, the size of leaf, the time of flowering, species more or less prickly, existence or non-existence of fuzz in the leaves or stem and right or branched vertical roots (Mozaffarian 2006). Animal species of the area were identified by direct observation, using the viewpoints of native people and also experts of Kabodarahang City Environment Protection Department (Mansoori 2001). Regarding that the said area is not under management of Department of Environment (DoE), Iran the native people and tourists appeared extensively in the area. This caused improper enumeration of animal species by the team members in the process of identification and this is one of the major constraints of this research.

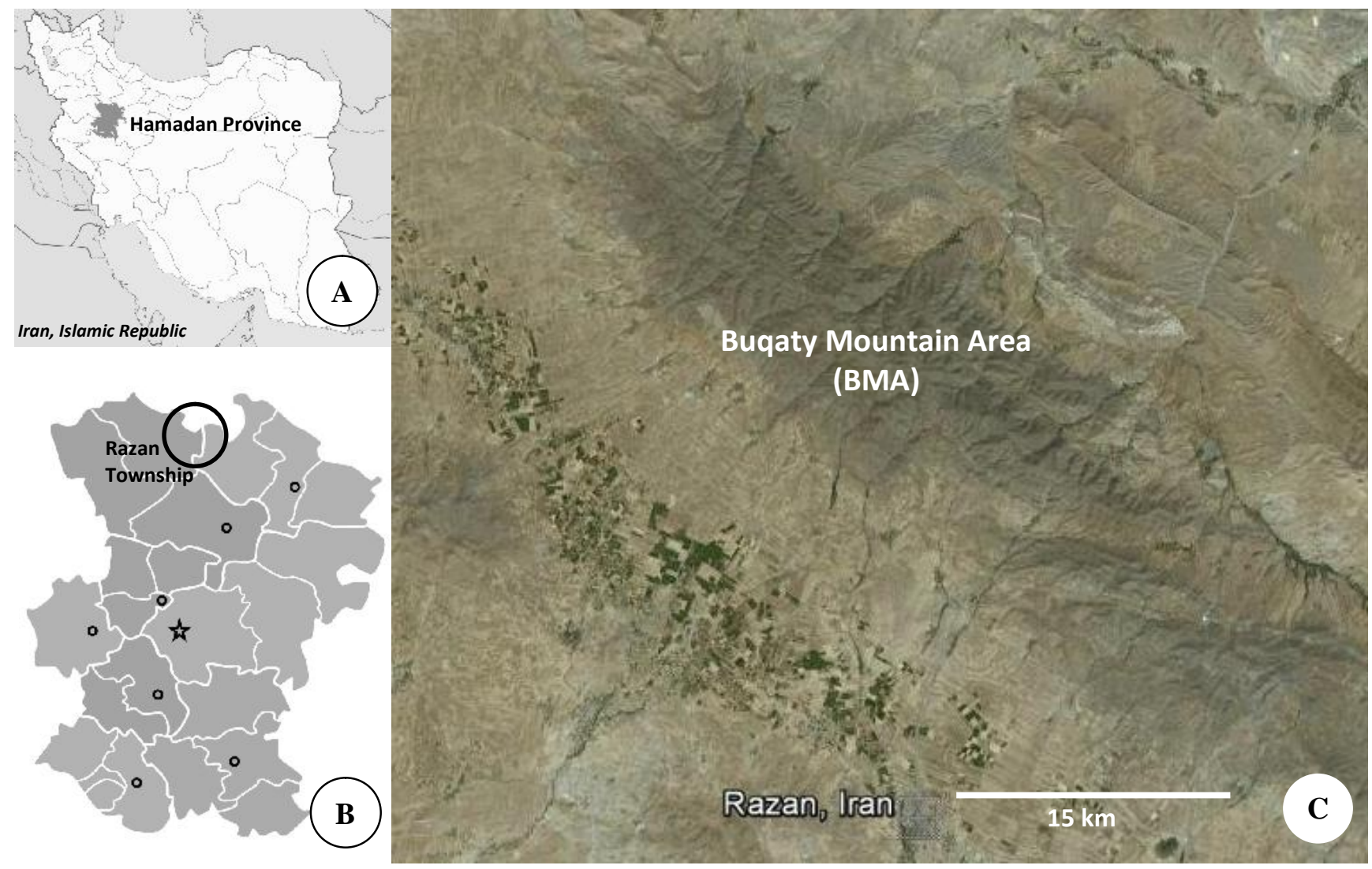

Figure 1. Location of the study area, A. Hamadan Province, Iran, B. Razan Township, C. Buqaty mountain area 
Table 1. List of plant species in BMA

\begin{tabular}{|c|c|c|}
\hline Species & Family & Uses \\
\hline Achillea tenuifolia & Asteraceae (Compositae) & Medical plant \\
\hline Alcea ficifolia & Malvaceae & Medical plant \\
\hline Alkanna bracteosa & Boraginaceae & Medical plant \\
\hline Allium haemanthoides & Liliaceae & Food plant \\
\hline Astragalus michauxii & Papilionaceae & Pasture plant \\
\hline Astragalus onobrychis & Papilionaceae & Pasture plant \\
\hline Astragalus senilis & Papilionaceae & Pasture plant \\
\hline Chaerophyllum aureum & Umbelliferae & Food plant \\
\hline Chamaemelum nobile & Asteraceae (Compositae) & Food plant \\
\hline Cirsium osseticum & Asteraceae (Compositae) & Food plant \\
\hline Erigeron acer & Asteraceae (Compositae) & Medical plant \\
\hline Francoeuria undulata & Asteraceae (Compositae) & Medical plant \\
\hline Geranium collinum & Geraniaceae & Ornamental plant \\
\hline Gundelia tournefortii & Asteraceae (Compositae) & Medical plant \\
\hline Hordeum bulbosum & Gramineae & Pasture plant \\
\hline Hypecoum pendulum & Papaveraceae & Medical plant \\
\hline Inula oculus-christii & Asteraceae (Compositae) & Medical plant \\
\hline Ixiolirion tataricum & Amaryllidaceae & Pastore plant \\
\hline Leucopoa sclerophylla & Gramineae & Pastore plant \\
\hline Londesia eriantha & Chenopodiaceae & Pastore plant \\
\hline Matricaria recutita & Asteraceae (Compositae) & Medical plant \\
\hline Muscari neglectum & Liliaceae & Pasture plant \\
\hline Phalaris paradoxa & Gramineae & Pastore plant \\
\hline Phlomis pungens & Labiatae & Medical plant \\
\hline Phlomis rigida & Labiatae & Food Plant \\
\hline Phyllitis scolopendrium & Aspleniaceae & Medical plant \\
\hline Plantago media & Plantaginaceae & Medical plant \\
\hline Prangos ferulacea* & Umbellifera & Pasture plant \\
\hline Rheum ribes* & Polygonaceae & Medical plant \\
\hline Salvia aethiopis & Labiatae & Pasture plant \\
\hline Satureja laxiflora & Labiatae & Medical plant \\
\hline Satureja macrantha & Labiatae & Medical plant \\
\hline Scorzonera cinerea & Asteraceae (Compositae) & Food Plant \\
\hline Senecio cineraria & Asteraceae (Compositae) & Ornamental plant \\
\hline Silene conoidea & Caryophyllaceae & Medical plant \\
\hline Sisymbrium irio & Cruciferae & Medical plant \\
\hline Sisymbrium loeselii* & Cruciferae & Pasture plant \\
\hline Stachys lavandulifolia & Labiatae & Medical plant \\
\hline Taraxacum syriacum & Asteraceae (Compositae) & Ornamental plant \\
\hline Trifolium repens & Papilionaceae & Medical plant \\
\hline $\begin{array}{l}\text { Trigonosciadium } \\
\text { brachytaenium }^{*}\end{array}$ & Umbelliferae & Pasture plant \\
\hline Trisetum flavescens & Gramineae & Pasture plant \\
\hline Vicia hyrcanica & Papilionaceae & Pasture plant \\
\hline Vicia pseudocassubica & Papilionaceae & Pasture plant \\
\hline
\end{tabular}

Note: * = endemic plant of Iran

\section{RESULTS AND DISCUSSION}

\section{Geographical status of the area}

BMA with a maximum height of 2800 meters above sea level is located in north of Hamadan Province and in the northwest of Razan Township. This area has an area of about 12,000 hectares and is one of the most valuable pastures of Iran with diverse plant coverage. BMA is a mountainous area with moderate climate and full of a wide range of herbal medicinal plant species in the area. The highest point in the said area is located in $48^{\circ}$, 41', 30.48" eastern longitude and $35^{\circ}, 32^{\prime}$, $49.20^{\prime \prime}$ northern latitude. The general height of the area is reduced toward the south and is then led to Kabodarahang plain (Figure 1). Based on the data gathered from the nearest meteorology stations, the average annual precipitation in the mentioned area is about $302 \mathrm{~mm}$ per year, the annual average of air temperature is $10.7^{\circ} \mathrm{C}$, the maximum average is $18.4^{\circ} \mathrm{C}$, the minimum average is $3.4^{\circ} \mathrm{C}$, and the average annual evaporation is $1682 \mathrm{~mm}$. There are several natural springs dispersed among the mountains and has caused massive amount tourists chose BMA as their favorite holidays.

\section{Diversity of plant species in the area}

Based on the results and observations, about 44 valuable plant species in BMA have been identified. Asteraceae, Labiatae and Papilionaceae families had the highest number of species (Figure 2). Some of these plants have pharmaceutical properties, some are used as forage crops and many of the said species have an important role in preserving water, prevent flood flowing and also preventing soil erosion on slops. Plant species diversity of the studied area is presented in table 1 . The plant species of BMA, which concerning plant coverage, is one of the most original and diverse areas of Iran. Every year in spring season, thousands of people from local areas and other provinces travel to BMA and harvest their desired traditional plants species using initial tools. Many species of Lamiaceae family plant have medical property and have been widely used in traditional medicine and the said species plants grow at different heights of the mentioned area. Among aromatic plants belonging to Lamiaceae family, the most popular ones are Salvia aethiopis, Satureja laxiflora and Satureja macrantha.

\section{Diversity of animal species in the area}

Regarding the ecological characteristics of the area and also according to pasture management which is applied relatively often, BMA is highly talented for growth and multiplication of various animal species including mammals and numerous birds. Based on the results, 45 bird species and 7 mammal species in BMA have been identified. Accipitridae and Turdidae families had the highest number of bird species (Figure 3). Animal species diversity of the studied area as birds and mammals is presented in Table 2 and 3. Also, unplanned presence of some tourists produced insecurity in many parts of Wildlife Habitats in the study area. On the other side, all of these have caused migration of Wildlife from their natural habitats to other areas. 


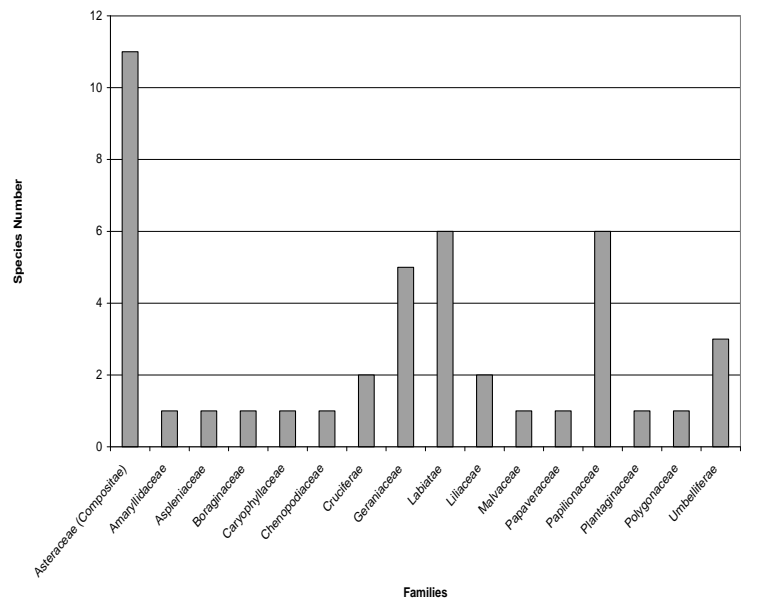

Figure 2. Number of species in each family of plants in BMA

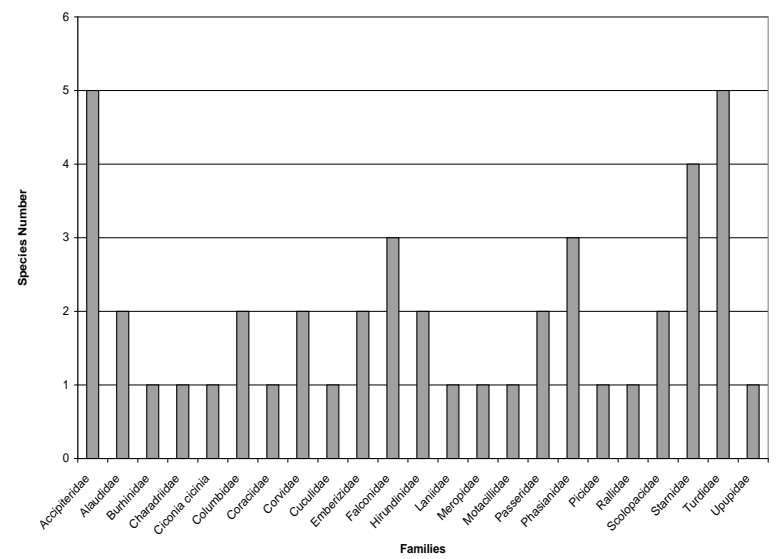

Figure 3. Number of Species in each family of Birds in BMA

A study was done in 2006 about Distribution system and its role about range destruction in BMA, it was found the way are used in BMA, is that range land exclusion (keeping livestock from entering the range land area) is applied every year until the pasture has made sufficient growth (almost up to $25^{\text {th }}$ June). Rangeland exclusion to livestock is one of the best management methods for range and watershed management that are applied for range rehabilitation and improvement. This method is used for increase in vegetation cover in watershed area that leads to increase in amount of land cover and consequently, causing stabilization of soil and reduction of soil loss rate. For this purpose, the ranger mans, that was called gorogban, is employed by stakeholders. In the end of exclusion period, the sub divisions of every grass pastures and every hill pastures as well as randomly classified and selected by the stakeholders. Later than, each stakeholder cut and collects the forage and carries them to the village. After cutting the forage material and finished the exclusion period, pasture grazing becomes possible and free for all of the villagers to graze their animals on. It is obvious that unlimited grazing of pasture is made after forage harvest (Vejdani and Solgi 2006).
Table 2. List of bird species in BMA

\begin{tabular}{|c|c|}
\hline Scientific name & Family \\
\hline Accipiter nisus & Accipitridae \\
\hline Alectoris chukar & Phasianidae \\
\hline Ammoperdix griseogularis & Phasianidae \\
\hline Aquila chrysaetos & Accipitridae \\
\hline Athene noctua & Strigidae \\
\hline Bubo bubo & Strigidae \\
\hline Burhinus oedicnemus & Burhinidae \\
\hline Buteo rufinus & Accipitridae \\
\hline Calandrella brachydactyla & Alaudidae \\
\hline Carduelis flavirostris & Fringillidae \\
\hline Ciconia cicinia & Ciconiidae \\
\hline Circus pygargus & Accipitridae \\
\hline Coracias garrulus & Coraciidae \\
\hline Corvus corone & Corvidae \\
\hline Corvus frugilegus & Corvidae \\
\hline Coturnix coturnix & Phasianidae \\
\hline Columba livia & Columbidae \\
\hline Cuculus canorus & Cuculidae \\
\hline Emberiza cia & Emberizidae \\
\hline Emberiza pusilla & Emberizidae \\
\hline Erithacus megarhynchos & Turdidae \\
\hline Erithacus rubecula & Turdidae \\
\hline Falco naumanni & Falconidae \\
\hline Falco peregrinus & Falconidae \\
\hline Galerida cristata & Alaudidae \\
\hline Gallinago gallinago & Scolopacidae \\
\hline Gyps fulvus & Accipitridae \\
\hline Hirundo rustica & Hirundinidae \\
\hline Lanius minor & Laniidae \\
\hline Merops orientalis & Meropidae \\
\hline Monticola saxatilis & Turdidae \\
\hline Motacilla cinerea & Motacillidae \\
\hline Oenantha isabellina & Turdidae \\
\hline Otus scops & Strigidae \\
\hline Passer domesticus & Passeridae \\
\hline Passer hispaniolensis & Passeridae \\
\hline Picoides minor & Picidae \\
\hline Porzana parva & Rallidae \\
\hline Riparia riparia & Hirundinidae \\
\hline Sturnus vulgaris & Sturnidae \\
\hline Streptopelia decaocto & Columbidae \\
\hline Turdus merula & Turdidae \\
\hline Tringa totamus & Scolopacidae \\
\hline Upupa epops & Upupidae \\
\hline Vanellus vanellus & Charadriidae \\
\hline
\end{tabular}

Table 3. List of mammal species in BMA

\begin{tabular}{ll}
\hline Scientific name & Family \\
\hline Paraechinus hypomelas & Erinaceidae \\
Canis lupus & Canidae \\
Canis aureus & Canidae \\
Capra aegagrus & Bovidae \\
Lepus europaeus & Leporidae \\
Sus scrofa & Suidae \\
Vulpes vulpes & Canidae \\
\hline
\end{tabular}


The results of the study may be compared to two other studies that have attempted to estimate the plant diversity in Lashgardar and Khan_Gormaz Protected Areas in Hamadan province. Both studies focused only on the plant diversity of these protected area. The first of these studies was accomplished by Safikhani et al. (2003) and reported that there are 43 families, 184 genera and 266 plant species in Lashgardar protected area. Based on the second study, Approximately 46 families, 180 genera and 261 plant species have been identified in Khan Gormaz Protected Area (Safikhani et al. 2006).

\section{CONCLUSION AND RECOMMENDATION}

Since Buqaty Mountain Area (BMA) have a substantial role in maintaining genetic resources, preserving biodiversity, production of medical herbs, biological control of plant pests and preservation of soil and water, it is necessary to combine different techniques for better exploitation of rangelands of the study area through teaching, educating, planning, investment, research and also evaluation of previous plans. In order to manage and control the natural beauty and full use of its potential, it is recommended that the area be declared as a prohibited hunting area by DoE for the conservation of flora and fauna and vested in the study area. It is obvious that the protection of BMA must be made in such a way as to guarantee the preservation and maintenance of the areas, increasing income of local people and also increasing the capacity of nature and environment.

\section{ACKNOWLEDGEMENTS}

This research was supported by Islamic Azad University (Hamadan Branch). The authors would like to thank department of environment of mentioned university. Also, the authors would like to thank Ahmad Yari, the expert of Hamadan provincial directorate of environmental protection, for their collaboration in this study.

\section{REFERENCES}

Bouayed J, Piri K, Rammal H, Dicko A, Desor F, Younos C, Soulimani R. 2007. Comparative evaluation of the antioxidant potential of some Iranian medicinal plants. Food Chem 104 (1): 364-368.
Demers M. 2009. Fundamental of Geographic Information System. John Wiley \& Sons, New York.

Kalvandi R, Safikhani K, Najafi GH, Babakhanlo P. 2007. Identification of medicinal plants of Hamedan province. Iranian J Med Aromatic Pl 23 (3): 350-374.

Koochak H, Seyyednejad SM, Motamedi H. 2010. Preliminary study on the antibacterial activity of some medicinal plants of Khuzestan (Iran). Asian Pac J Trop Med 3 (3):180-184.

Mansoori J. 2001. Field guide to the birds of Iran. Nashre Zehn Aviz, Tehran, Iran.

Mirutse Giday M, Asfaw Z, Woldu Z. 2009. Medicinal plants of the Meinit ethnic group of Ethiopia: An ethnobotanical study. J Ethnopharmacol 124 (3): 513-521.

Mosaddegh M, Naghibi F, Moazzeni H, Pirani A, Esmaeili S. 2012. Ethnobotanical survey of herbal remedies traditionally used in Kohghiluyeh va Boyer Ahmad province of Iran. J Ethnopharmacol 141 (1): 80-95.

Mozaffarian VA. 2006. A dictionary of Iran plant names. Farhang Moaser publisher, Tehran, Iran.

Nadembega P, Boussimb J.I, Nikiemac J.B, Polia F, Antognonia F., 2011, Medicinal plants in Baskoure, Kourittenga Province, Burkina Faso: An ethnobotanical study. J Ethnopharmacol 133 (2): 378-395.

Reyahi-Khoram M, Karami-Nour M. 2010. A Case Study on Environmental Evaluation and Planning for Range and Forest Management by Means of Geographic Information System (GIS). J Agric Sci Technol 4 (6): 57-62.

Rihawy MS, Bakraji EH, Aref S, Shaban R. 2010. Elemental investigation of Syrian medicinal plants using PIXE analysis. Nuclear Instruments and Methods in Physics Research Section B, Beam Interactions with Materials and Atoms 268 (17-18): 2790-2793.

Russell-Smith J, Karunaratne NS, Mahindapala R. 2006. Rapid inventory of wild medicinal plant populations in Sri Lanka. Biol Conserv 132 (1): 22-32.

Safikhani K, Rahiminejhad MR Kalvandi R. 2003. Presentation of flora, life forms, endemic species and their conservational classes in protected region of Lashkardar (Malayer city-Hamadan province). Pajouhesh \& Sazandegi 60: 72-83

Safikhani K, Rahiminejhad MR, Kalvandi R. 2006. Presentation of flora and life forms of plants in protected region of Khangormaz (Hamadan province). Pajouhesh \& Sazandegi 70: 70-78.

Shahidi B. 2004. Evaluation of antibacterial properties of some medicinal plants used in Iran. J Ethnopharmacol 94 (2-3): 301-305.

Suneetha MS, Chandrakanth MG. 2006. Establishing a multi-stakeholder value index in medicinal plants-an economic study on selected plants in Kerala and Tamilnadu States of India. Ecol Econ 60 (1): 3648.

Tilahun-Teklehaymanot T, Giday M. 2010. Quantitative ethnobotany of medicinal plants used by Kara and Kwego semi-pastoralist people in lower Omo River Valley, Debub Omo Zone, Southern Nations, Nationalities and Peoples Regional State, Ethiopia. J Ethnopharmacol 130 (1): 76-84.

Ulukanli Z, Akkaya A. 2011. Antibacterial Activities of Marrubium catariifolium and Phlomis pungens Var. Hirta Grown Wild in Eastern Anatolia, Turkey. Intl J Agric Biol 13 (1): 105-109.

Vejdani HR, Solgi M. 2006. Distribution system and its role about range destruction. Proceeding of the First National Festival on Range and Rangeland Management, Mashhad, Iran. 